\title{
COST EFFICIENCY IN AUSTRALIAN GENERAL INSURERS: A NON-PARAMETRIC APPROACH
}

\author{
ANDREW C. WORTHINGTON \\ Queensland University of Technology, Australia \\ EMILY V. HURLEY \\ Commonwealth Department of the Treasury, Australia
}

\begin{abstract}
Data envelopment analysis is used to calculate pure technical, scale, allocative and cost efficiency indices for a sample of forty-six Australian general insurers. The inputs used are labour, physical capital (in the form of both information technology and plant and equipment) and financial capital. The outputs are net premium revenues for housing-related, transport-related, indemnity-related, mortgage-related and other insurance, along with invested assets. The results indicate that the major source of overall cost inefficiency would appear to be allocative inefficiency, rather than technical inefficiency, and that the largest twenty percent of insurers are significantly more efficient than the remaining firms. A second-stage analysis uses limited dependent variable regression techniques to relate efficiency scores to firm-specific information. Cost efficiency appears to be closely related to asset size but not to stock exchange listing or product diversification or specialisation.
\end{abstract}

This is the author-manuscript version of this paper. Published in:

Worthington, Andrew and Hurley, Emily (2002) Cost Efficiency In Australian General Insurers: A Non-Parametric Approach. British Accounting Review 34(1):pp. 89-108.

Copyright 2002 Elsevier

\section{INTRODUCTION}

In March $2001 \mathrm{HIH}$ Insurance Limited, Australia's second-largest general (non-life) insurer, went into liquidation with unfunded liabilities of \$5 billion. Amid claims that $\mathrm{HIH}$ 'window-dressed' its financial performance, understated its liabilities and used inaccurate accounting, a far-reaching royal commission was instigated in December 2001. The commission was directed to examine, amongst other things, HIH's management, system of incentive payments, corporate culture, accounting practices, recent acquisitions and investments and reinsurance arrangements. At the same time, questions surrounding the

The authors would like to thank participants at the Irish Accounting and Finance Association Annual Conference, Dublin Institute of Technology and two anonymous referees for helpful comments on an earlier version of this paper. The assistance of the Australian Prudential Regulation Authority (APRA) in providing the requisite data and the financial support of a Queensland University of Technology, Faculty of Business Research Initiative Grant is also gratefully acknowledged. The opinions expressed here are the authors and not necessarily those of the Commonwealth Department of the Treasury.

Please address all correspondence to: Dr. Andrew Worthington, School of Economics and Finance, Queensland University of Technology, GPO Box 2434, Brisbane, QLD 4001, Australia, Tel.: (617) 3864 2658, Fax: (617) 3864 1500, email: a.worthington@qut.edu.au 
efficacy of prudential supervision have focused criticism on the role of the Australian Prudential Regulation Authority (APRA) as the industry regulator. This has manifested itself most abundantly in a set of new prudential standards for general insurance companies. The proposed standards include strict requirements for the reliable and consistent valuation of liabilities and the provision of sound reinsurance arrangements, exacting risk-adjusted levels of capital and standards governing the transfer and amalgamation of insurance business, and directives to promote strong corporate governance and access to independent advice.

However, even before the collapse of $\mathrm{HIH}$ the Australian general insurance industry has been regarded as troubled. One overriding concern has been the absence of the postderegulation efficiency improvements so noticeable in other sectors of the financial services industry. For example, the Wallis Inquiry (1997) found that Australian general insurers were still operating at costs well above international best practice. At the same time, general insurers have increasingly been working on a global basis, and competition between banks and insurers in Australia has intensified as regulations delineating the two services have been relaxed. Combined with the need to maximise economies of scale to improve distribution efficiency, reduce costs and spread information technology expenses over a larger base, the industry has become increasingly concentrated (KPMG, 1999). For instance, the five largest general insurance groups accounted for 47 percent of premium income in 1997, and this share had increased to 63 percent by 1999. Unfortunately, while these larger insurers have increasingly diversified product lines it is unknown what impact sharing costs actually has on insurer efficiency.

Concurrently, continued pressure on premium rates, and the deterioration of claims and expense ratios combined with customer demand for better quality services, has provided a mixed outlook for general insurers. With a large number of firms, strong competition and relatively low barriers to entry, it is generally accepted that there are too many firms in the domestic market for long-run sustainability (KPMG, 1999). Furthermore, with the insurance industry being on the WTO agenda for international reform for the first time, it is expected that the convergence of world markets will put increasing amounts of pressure on Australian general insurers to increase efficiency to survive (WTO, 2000). It is expected that many of the smaller, more specialised and less-efficient insurers will be at risk. Notions of efficiency, especially cost efficiency, thereby lie at the core of our understanding of the insurance industry.

The importance and measurement of efficiency in the insurance industry also dovetails neatly with the broader programs of accounting research. Provided with externally reported accounting information regulators, shareholders, policyholders and the markets for corporate control and managerial labour are faced with the need to derive meaningful measures of insurer cost efficiency. This has much relevance to financial accounting and corporate governance research examining, at least in part, the role of accounting information. Likewise, in managerial accounting and value-based management the strategic cost management literature has focused on the drivers of costs (including scale and scope economies) and the ability of the organisation to execute its operations cost efficiently and effectively, while the balanced scorecard concept has emphasised the use of multiple dimensions of non-financial performance as indicators of future financial performance. These suggest that an understanding of efficiency in general insurers is of use not only to finance researchers interested in the viability of an important sub-sector of the financial services industry, but also to accounting researchers concerned with new perspectives on the usefulness of accounting information.

Unfortunately, almost no empirical evidence exists concerning the pattern of cost efficiency in Australian general insurers. First, while there have been numerous international 
efficiency studies conducted in other areas of the financial services industry, especially deposit-taking institutions, only a handful have been concerned with insurance services. A thorough examination of efficiency would throw light on future pressures for consolidation, highlight concerns for regulators, and indicate the ability of domestic general insurance companies to compete in the increasingly globalised insurance business.

Second, most analyses of insurance company efficiency have tended to concentrate on life insurers [examples include Fukuyama (1997) Hardwick (1997), Cummins \& Santomero (1999), Cummins, Tennyson \& Weiss (1999), and Meador et al. (2000)] or single product lines such as property-liability insurance [see, for instance, Doherty (1981), Weiss (1992), Berger et al. (1997) and Cummins, Weiss \& Zi (1999)]. By comparison, non-life (general) insurance services have attracted relatively little attention (Prosperetti, 1991). Third, many studies have also tended to rely upon simple cost function approaches [see, for example, Bernstein (1992), Grace \& Timme (1992) and McIntosh (1998)] with a smaller number of analyses taking advantage of the sizeable advances in frontier efficiency measurement techniques. Finally, many studies to date have concentrated on technical and/or scale efficiencies, and have generally ignored allocative efficiency. This is important because allocative efficiency is likely to be a major component of overall cost efficiency and is generally accepted to be the area most likely to have improved during the process of financial deregulation and globalisation.

With these considerations in mind, an attempt is made to examine the cost efficiency of the Australian general insurance industry. The purposes of this exercise are twofold. To start with, we calculate measures of pure technical, scale, allocative and cost efficiency using nonparametric methods. This represents the first attempt at calculating frontier measures of efficiency in the Australian insurance industry and should provide valuable information for managers, policyholders, shareholders and regulators. The second part of the analysis uses these measures of efficiency to examine the three most pertinent concerns in the Australian insurance industry; namely, the putative link between insurer size, product line diversification, organisational form and efficiency.

The paper itself is divided into four main areas. The first section explains the nonparametric technique used in the measurement of general insurer cost efficiency. The second section deals with the specification of inputs and outputs in this model. The results are dealt with in the fourth section. The paper ends with some brief concluding remarks in the final section.

\section{EMPIRICAL METHODOLOGY}

There are three basic forms of efficiency: technical efficiency, or the ability of a firm to maximise output from a given set of inputs, allocative efficiency, or the ability of a firm to use these inputs in optimal proportions given their respective prices, and the combination of technical and allocative efficiency referred to as cost efficiency. The methodology employed in the current paper to empirically construct measures of cost, allocative and technical efficiency is based upon the data envelopment analysis (DEA) approach to efficiency measurement. Fukuyama (1997), Cummins \& Zi (1998) and Cummins, Tennyson \& Weiss (1999), amongst others, have applied this approach to insurance companies. Suitable introductions to DEA may be found in Coelli et al. (1997) and Cooper et al. (2000) while Berger \& Humphrey (1997) provide a comprehensive survey of the various approaches to efficiency measurement in financial institutions. 
In brief, the advantages and disadvantages of the DEA approach to efficiency measurement are as follows. To start with, one obvious problem with DEA is that in contrast to the econometric approaches to efficiency measurement it is both nonparametric and nonstochastic. Thus, no accommodation is made for the types of bias resulting from environmental heterogeneity, external shocks, measurement error, and omitted variables. Consequently, the entire deviation from the frontier is assessed as being the result of inefficiency. This may lead to either an under or over-statement of the level of inefficiency.

However, there a number of benefits implicit in the mathematical programming approach that makes it attractive on a theoretical level. First, given its nonparametric basis it is relatively easy to alter the specification of inputs and outputs and thereby the formulation of the production correspondence relating inputs to outputs. Thus, in general insurance where the product of mix of individual insurers varies considerably, the programming approach offers useful insights. Second, when using the alternative econometric approach considerable structure is imposed upon the data from both stringent parametric form and distributional assumptions regarding both inefficiency and, in the case of stochastic frontiers, statistical noise. These considerations, and the natural emphasis of DEA on the notion of 'best-practice' performance, make it an attractive method of measuring efficiency in financial institutions.

The computational procedure used to implement the DEA approach to cost efficiency measurement consists of two steps. The first step is to obtain measures of technical efficiency as introduced by Charnes et al. (1978). Consider $N$ general insurers each producing $M$ different outputs using $K$ different inputs. The $K \times N$ input matrix, $X$, and the $M \times N$ output matrix, $Y$, represent the data of all $N$ general insurers, while for the individual general insurer these are represented by the vectors $x_{i}$ and $y_{i}$.

The purpose of DEA is to construct a non-parametric envelopment frontier over the data points such that all observed points lie on or below the production frontier. The relative efficiency of each general insurer in ratio form (where for each general insurer we obtain a ratio of all outputs over all inputs) is specified as follows:

$$
\begin{array}{r}
\max _{u, v}\left(u^{\prime} y_{i} / v^{\prime} x_{i}\right) \\
\text { s.t. } u^{\prime} y_{j} / v^{\prime} x_{j} \leq 1 \\
u, v \geq 0
\end{array}
$$

where $y_{i}$ is the vector of outputs produced by the $i$ th general insurer, $x_{i}$ is the vector of inputs used by the ith general insurer, $u$ is a $M \times 1$ vector of output weights and $v$ is a $K \times 1$ vector of input weights (the prime denotes a transposed vector), $i$ runs from 1 to $N$, and $j$ equals $1,2, \ldots$, $N$. The first inequality ensures that the efficiency ratios for all general insurers cannot exceed one, whilst the second ensures that the weights are non-negative. The weights are determined such that each general insurer maximises its own efficiency ratio.

One problem with this particular ratio formulation is that it has an infinite number of solutions. To avoid this the constraint $v^{\prime} x_{i}=1$ is imposed. This fractional linear program (1) can then be transformed into the following equivalent linear programming problem: 


$$
\begin{array}{r}
\max _{\mu, v}\left(\mu^{\prime} y_{i}\right) \\
\text { s.t. } v^{\prime} x_{i}=1 \\
\mu^{\prime} y_{j}-v^{\prime} x_{j} \leq 0 \\
\mu, v \geq 0
\end{array}
$$

where the notation change from $u$ and $v$ to $\mu$ and $v$ reflects the transformation. Using the duality of linear programming, this multiplier form can then be used to derive an equivalent envelopment form of the problem:

$$
\begin{aligned}
& \min _{\theta, \lambda} \theta \\
& \text { s.t. }-y_{\mathrm{i}}+Y \lambda \geq 0 \\
& \theta x_{i}-X \lambda \geq 0 \\
& \lambda \geq 0
\end{aligned}
$$

where $\theta$ is a scalar and $\lambda$ is a $N \times 1$ vector of constants. The value of $\theta$ will be the technical efficiency score for a particular general insurer. It will satisfy $\theta \leq 1$, with a value of 1 indicating a point on the frontier, and hence a technically efficient general insurer. The value of $\theta \leq 1$ identifies the amount of any inefficiencies that may be present.

The model specified in (3) has an assumption of constant returns-to-scale and is only appropriate where all general insurers are operating at an optimal scale. Where this assumption does not hold, scale effects will confound the measures of technical efficiency (TE). We would normally assume that many general insurers are not operating at an optimal scale. Following Banker et al. (1984) the linear programming problem can be modified to account for variable returns-to-scale by adding the convexity constraint $N 1^{\prime} \lambda=1$ to (3). The measure of technical efficiency obtained in this instance is often referred to as pure technical efficiency (PTE). Dividing TE by PTE then provides a measure of scale efficiency (SE).

The second step is to calculate cost efficiency with respect to this DEA dual reference technology by solving the following linear program (including the convexity constraint):

$$
\begin{aligned}
& \min _{\lambda, x_{i}^{*}} w_{i}^{\prime} x_{i}^{*} \\
& \text { s.t. }-y_{i}+Y \lambda \geq 0 \\
& x_{i}^{*}-X \lambda \geq 0 \\
& N 1^{\prime} \lambda=1 \\
& \lambda \geq 0
\end{aligned}
$$

where $w_{i}$ is a vector of input prices for the ith general insurer and $x_{i}{ }^{*}$ is the cost-minimising vector of input quantities for the ith general insurer given the input price vector $w_{i}$ and the output vector $y_{i}$. The ratio $\left(w_{i}{ }^{\prime} x_{i}{ }^{*} / \mathrm{w}_{i}{ }^{\prime} x_{i}\right)$ measures the cost efficiency $(C E)$ of the $i$ th general insurer, and $\left[\left(w_{i}{ }^{\prime} x_{i}{ }^{*} / \mathrm{w}_{i}{ }^{\prime} x_{i}\right)^{-1}-1\right]$ measures the amount by which cost is increased due to both kinds of inefficiency (both technical and allocative): that is, the ratio of minimum to observed cost. Following the earlier discussion, allocative efficiency $(A E)$ can then be calculated residually by dividing cost efficiency $(C E)$ by technical efficiency $(T E)$.

The primary technique used for explaining variation in the various efficiency measures is a regression-based approach. In this model, the calculated measures of pure technical efficiency $(P T E)$, scale efficiency (SE), allocative efficiency $(A E)$ and cost efficiency (CE) for all general insurers (both efficient and inefficient) are specified as the dependent variable in four separate regressions. Given that in each case the calculated measure of efficiency is a limited 
dependent variable, tobit estimation is appropriate. The explanatory variables posited to explain the presence of inefficiency are a set of firm-specific characteristics that characterise each general insurer's operations.

\section{SPECIFICATION OF VARIABLES}

Summary statistics of the inputs, input prices and outputs used in the calculation of the nonparametric efficiency measures are detailed in Table 1 . All data corresponds to the year ending 31 December 1998 and is obtained from the Australian Prudential Regulatory Authority (APRA). Following recommendations by the Wallis Inquiry (1997) APRA is now the sole prudential regulator of banks, credit unions, building societies, insurance and superannuation companies, prior to which this function was divided amongst a number of regulatory bodies. The data collected contains information relating to profit and loss and balance sheet information, as well as additional information concerning expenses. At least some part of this data is publicly available information while other parts are confidential releases that have been made available for the first time. Unfortunately, no other crosssections of data have been compiled to date.

As at 31 December 1998 there were 172 private sector insurers supervised under the Insurance Act 1973. This total was composed of 106 direct underwriters, 15 mortgage insurers, 6 captive insurers, 29 reinsurers, and 16 other insurers. Although all of these insurers fall under the same legislation they have highly differentiated functions. Therefore, the sample was narrowed to those specifically operating as direct underwriters. From this group of 106 firms, the smallest 60 firms were discarded due to lack of sufficient data leaving 46 firms to use for the analysis.

Following much existing work in the area, the main insurance outputs $(y)$ in this analysis are specified as net premium income for each insurance line, defined as premium revenue less reinsurance expense [see, for example, Praetz (1980), Grace \& Timme (1992), Gardner \& Grace (1993), Rai (1996) and Hardwick (1997)]. In one sense, defining outputs in this manner has some intuitive appeal given that premium income is paid to insurers by policyholders (usually annually) in order to 'buy' risk protection. Houston \& Simon (1970, p. 856), for example, argued, "premiums paid is used as a proxy for output which is analogous to measuring output as total sales". Additional issues associated with defining output in the service sector are taken up in Berger \& Humphrey (1993).

However, and notwithstanding the widespread acceptance of premium income as an indicator of insurance output, it is acknowledged that there are a number of limitations associated with this measure. The main consideration is that premiums actually measure price multiplied by output, and not just output. Therefore any difference in the price of premiums across insurers could lead to misleading inferences concerning relative efficiency (Yuengert, 1993). As an alternative, a number of studies have used additions to reserves to measure output, including Yuengert (1993) and Fukuyama (1997). It is argued that additions to reserves is a more adequate reflection of productive behaviour since it incorporates reserves arranged for new business, new deposit funds and new reserves as established policies age. Nevertheless, defining output in terms of reserves still suffers from the limitation that it is not immune to differences in prices across firms and alternative actuarial practices (Yuengert, 1993).

A still further alternative exists where insurance output is defined as the present value of real losses incurred (Cummins \& Weiss, 1993; Berger et al., 1997; Cummins et al., 1999). Cummins et al. (1999: 1260) argue as follows: 
The rationale for the use of losses to proxy for insurance output is that the primary function of insurance is risk pooling, i.e., the collection of funds from the policyholder pool and the redistribution of funds to those pool members who incur losses. Losses are also a good proxy for 'real services' provided by insurers such as coverage design and providing legal defense in liability suits.

Nevertheless, Berger et al. (1997) have argued that such a measure also has its shortcomings, at least within the context of comparing direct writers and independent-agency insurers in property-liability insurance. First, although services are likely to be highly correlated with real losses, "measured losses will not capture any systematic differences between direct writers and independent-agency insurers in the levels of service intensity per dollar of loss. Such differences...cannot be well measured by losses or any other observable variables" (Berger et al., 1997, p. 526). Second, it is argued that the use of losses to measure insurance output ignores the output qualities of loss control and risk management. Berger et al. (1997, p. 526) offer a cogent argument: "an insurer that is very successful in its underwriting and loss-prevention practices will incur fewer losses for the same amount of premiums written but will be measured as having less output”.

The fact remains that some of the most appropriate measures of insurance output, including the numbers of applications processed, policies issued and renewed, and claims settled, are rarely collected nor made available. And depending upon the proxy employed, the outputs employed in the literature are likely to ignore the varying prices and profiles of insurance services and important insurance functions such as risk bearing/pooling. Unfortunately, detailed information of this type is not presently available for Australian general insurers. Accordingly, the main outcome in the use of net premiums is that the results will be relatively dependent on variance in product pricing and are likely to overstate the level of actual insurance output by making no allowance for important functions such as risk management.

While the data collected by APRA does not contain information on additions to reserves nor incurred losses, the data is rich in information about premium income divided into various insurance lines and includes figures relating to reinsurance, which is a major influence on the overall net underwriting result. Five categories of insurance product are specified as outputs in Table 1. These are: (i) housing-related insurance (HSE) (mainly home and contents insurance); (ii) transport-related insurance (TRN) (including commercial and domestic motor vehicle insurance, compulsory third party and marine and aviation insurance); (iii) indemnityrelated insurance (IND) (including professional indemnity, employer's liability and public and product liability insurance); (iv) mortgage-related insurance (MOR); and (v) 'other' insurance $(O T H)$ (including relatively minor products such as travel, consumer credit and other miscellaneous insurance). The shares of industry activity (including reinsurance) for these product lines range from less than 1 percent for travel insurance (included in OTH) up to 45 percent for transport-related insurance. 
TABLE 1

Selected descriptive statistics, inputs and outputs

\begin{tabular}{|c|c|c|c|c|c|}
\hline & Variable & Description & Mean & $\begin{array}{l}\text { Standard } \\
\text { deviation }\end{array}$ & $\begin{array}{l}\text { Coefficient } \\
\text { of variation }\end{array}$ \\
\hline \multirow{6}{*}{ 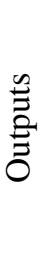 } & HSE & Housing-related insurance net premium income (\$) & 36084.26 & 67708.76 & 1.87 \\
\hline & TRN & Transport-related insurance net premium income (\$) & 46084.13 & 104382.06 & 2.26 \\
\hline & IND & Indemnity-related insurance net premium income (\$) & 13827.56 & 30135.58 & 2.17 \\
\hline & MOR & Mortgage-related insurance net premium income (\$) & 469.41 & 2058.03 & 4.38 \\
\hline & $\mathrm{OTH}$ & Other insurance net premium income (\$) & 9842.37 & 18033.58 & 1.83 \\
\hline & INV & Invested assets (\$) & 316858.41 & 892823.65 & 2.81 \\
\hline \multirow{4}{*}{ 节 } & LAB & Labour expenses (\$) & 20962.67 & 51135.24 & 2.43 \\
\hline & INF & Information technology expenses (\$) & 1442.37 & 5599.88 & 3.88 \\
\hline & PHY & Physical capital expenses (\$) & 1654.87 & 4793.26 & 2.89 \\
\hline & FIN & Financial capital expenses (\$) & 395.58 & 2363.54 & 5.97 \\
\hline \multirow{4}{*}{ 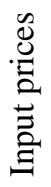 } & SAL & Price of labour (\$) & 41.87 & - & - \\
\hline & DEI & Price of information technology (\%) & 27.00 & - & - \\
\hline & DEP & Price of physical capital (\%) & 13.00 & - & - \\
\hline & INT & Price of financial capital (\%) & 10.28 & - & - \\
\hline \multirow{2}{*}{ 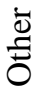 } & AST & Total assets (\$) & 455968.10 & 1046760.70 & 2.29 \\
\hline & HRF & Herfindahl index of insurance product concentration & 0.66 & 0.26 & 0.40 \\
\hline
\end{tabular}

Notes: This table provides sample means, standard deviations and coefficients of variation for general insurer inputs, input prices, outputs and quantitative explanatory variables. All dollar values are in thousands of Australian dollars.

Finally, and in addition to the five outputs concerning the net underwriting results of general insurers, an additional output is specified in the form of total invested assets (INV) (Berger \& Humphrey, 1993). This is also a well-established choice of output since most general insurance net profit comes from the intermediation function of borrowing from policyholders and investing in marketable securities rather than premiums [see, for instance, Gardner \& Grace (1993), Grace \& Timme (1992) and Berger et al. (1997)]. In 1998, approximately 22 percent of total assets were held in equity and trust holdings, 23 percent in interest-bearing securities and 11 percent in cash, deposits and placements.

The inputs $(x)$ and input prices $(w)$ used in the calculation of the efficiency measures are also presented in Table 1 . The four inputs selected are labour expenses ( $L A B)$, expenses on information technology (INF), expenses on other physical capital (PHY), and expenses on financial capital $(F I N)$. Justification for specifying insurance inputs in this manner is as follows. First, labour is generally accepted as being one of the most important expenses in the insurance industry accounting for some two-thirds of non-loss expense in Australia. In this study, labour is defined as the sum of expenses on commissions on premiums, salaries, wages and benefits and management fees. This follows the work of Grace \& Timme (1992) and Rai (1996), amongst others.

Second, physical capital, which is normally summed together, is divided into two parts. The first part consists of information technology expenses, which includes computers and computer software. The second part includes expenses on items such as furniture, fittings, plant and equipment. Grace \& Timme (1992), Gardner \& Grace (1993), Rai (1996) and Cummins \& Zi (1998) also specified physical capital as an insurance service input. Rent, land and buildings expenses are deliberately omitted, for while insurance companies do hold large real estate portfolios, this is usually due to investment rather than operational purposes.

The final input comprises an indication of the cost of obtaining financial capital. As an alternative, a number of studies have used equity capital (or equivalent) as a measure of input 
[see, for example, Cummins \& Weiss (1993), Cummins \& Zi (1998) and Cummins et al. (1999)]. Unfortunately, many insurance companies in Australia are unlisted and the data collected by APRA does not contain an equivalent measure. Therefore, although it is not the optimal proxy for financial capital, borrowing expense is used in this study.

The prices $(w)$ for each of these input quantities are assumed to be constant across all firms in the sample given that general insurers purchase their inputs in competitive markets. The average gross weekly earnings of all persons employed in the finance and insurance industry (Australian Bureau of Statistics, Catalogue No. 6302.0) specifies the wage rate (Grace \& Timme 1992; Cummins \& Zi 1998). The price of information technology (DEI) is the prime cost depreciation rate over 5 years for computers, and the price of furniture, fittings, plant and equipment (DEP) is the prime cost depreciation rate over 15 years (Hardwick, 1997). Lastly, the price of financial capital (INT) is specified as the long-term rate of return on Australian equity. All non-labour input price data is obtained from the Treasury Model of the Australian Economy (Australian Bureau of Statistics, Catalogue No. 1364.0).

As a way of explaining variation in efficiency across Australian general insurers, a secondstage procedure is used to relate measures of pure technical, scale, allocative and cost efficiency to a set of explanatory variables presumed to account for differences in efficiency. These explanatory variables are intended to evaluate several associated hypotheses on the relationships between financial institution inefficiency and firm-specific variables.

In this methodology, the index measures of efficiency are specified as the dependent variables in a regression-based approach. General insurers with efficiency scores less than one are relatively 'inefficient'. For example, an insurance company with a cost efficiency score of 0.75 is only three-quarters as cost efficient as the 'efficient' insurers that define the best-practice frontier, while one with an efficiency score of 0.90 is only ten percent less cost efficient. A positive estimated coefficient in the regression model is thereby associated with an improvement in efficiency, while a negative coefficient is linked with a reduction in efficiency. Summary statistics for the quantitative variables are detailed in Table 1 . The explanatory variables include (i) the log of total assets (AST), (ii) the log of total assets squared $\left(A S T^{2}\right)$, (iii) a dummy variable indicating whether the insurance company is a listed (LST) or unlisted company, and (iv) a Herfindahl index of product market specialisation $(H R F)$. These four variables are closely related to the specific conditions already discussed in the Australian insurance industry.

The first two independent variables are the natural logarithm of the firm's book value of assets $(A S T)$ as a proxy for size and the square of this term $\left(A S T^{2}\right)$ to account for the nonlinear size-efficiency relationship (Meador et al., 2000). For example, on the basis of estimates of these parameters, Meador et al. (2000, p. 194) concluded:

[W]e estimate a negative coefficient on the natural logarithm of total assets and a positive coefficient on its square, suggesting that [life insurance companies] of approximately medium size are relatively less X-efficient.

As an alternative, Cummins et al. (1999) used dummy variables for differing size quartiles to compare the impact of asset size across mutual and stock property-liability insurers. They suggested "...that large mutuals are more likely to suffer from agency problems than smaller mutuals, i.e., that the stock organizational form's superior control mechanisms are more important in larger organizations" (Cummins et al., 1999, p. 1266).

Second, a dummy variable is included to distinguish between listed stock (LST) and unlisted stock and mutual forms of general insurers, and is drawn from the well-established principal-agent literature. Work by Weiss (1981) and Fields (1988) has used a similar approach to quantify the impact of differences of ownership on insurance company efficiency. 
However, Fields (1988) and Fukuyama (1997) found no differences between the alternative organisational forms, while Cummins \& Van Derhei (1979) found stock companies to be more inefficient than mutuals. An important consideration is that in the Australian insurance industry only one major general insurer retains a mutual form (KPMG, 1999). However, the majority of stock companies remain unlisted. Hence, this analysis will test for a significant difference between insurers that are listed and those that are not. It is posited that listed companies should be more efficient than unlisted companies because listed companies are exposed to the markets for corporate control and stricter regulatory oversight by the Australian Stock Exchange (ASX).

The fourth independent variable reflects the fact that a common explanatory factor for differences in insurance company efficiency is the degree of firm specialisation or 'focus' (Meador et al., 2000). In general, cost sub-additivity implies cost savings from one firm producing a set of products as compared to the cost of separate firms producing separate lines. Evidence to date is mixed. In a sample of Canadian insurers, Bernstein (1992) found that significant savings occurred when producing multiple products, while Fields (1988) and Fields and Murphy (1989) found nothing to suggest that scope economies existed in the US industry. Alternatively, in a study of the US life insurance industry Meador et al. (2000, p. 189) concluded, "these results provide evidence that life insurers offering a diversified product mix have achieved greater average X-efficiency than focused [life insurers]".

Following Hardwick (1997), Cummins et al. (1999) and Meador et al. (2000), a Herfindahl index $(H R F)$ is used to measure the extent to which firms specialise or diversify their production of insurance services (calculated by summing the squared proportions of total premium revenue for each product class). A general insurer that specialises in a single insurance product line will have a Herfindahl index of one, while a lower Herfindahl index (bound by zero) will indicate a broader range of product lines. Following the assumption of cost complementariness a negative coefficient is hypothesised when efficiency is regressed against this measure of product line specialisation. As an alternative, Meador et al. (2000: 178) argue "managers generate cost savings by concentrating their financial and human resources in a single area of expertise”. If the cost savings associated with this 'concentration hypothesis' outweigh that of the 'diversification hypothesis' then a positive coefficient may be obtained when efficiency is regressed on HRF.

\section{EMPIRICAL RESULTS}

Table 2 provides summary statistics for the DEA measures of Australian general insurance companies pure technical, scale, allocative and cost efficiency. The inputs used are labour, physical capital (in the form of both information technology and plant and equipment) and financial capital. The outputs are premium revenue less reinsurance expenses for housingrelated insurance, transport-related insurance, mortgage-related, indemnity-related and other insurance along with invested assets. The factor prices used are the implied prices of labour, physical capital and the rate on long-term borrowings. The measure of overall cost inefficiency therefore incorporates both allocative inefficiencies, which result from failing to react optimally to relative prices of inputs, and technical inefficiencies from employing too much of the inputs to produce the outputs.

The first sets of descriptive statistics in Table 2 are those relating to the entire sample (ie. all insurers). As indicated, of the 46 general insurers examined, 28 insurers (or 60 percent) are judged pure technically efficient (that is, with an efficiency index equal to one), while 19 insurers (some 41 percent) are scale efficient. The results for pure technical efficiency indicate that, on average, inputs could be reduced to 76.2 percent of the current level based 
upon observable best-practice, whilst the results for scale efficiency suggest that efficiency losses due to scale effects account for 27.1 percent of inputs (that is, 1.000-0.729). In general, many insurers are either pure technically efficient or nearly so, with 75 percent of institutions having an efficiency score greater than 50.9 percent. On the other hand, 75 percent of general insurers are less than 91.6 percent scale efficient when compared to best practice.

However, a large number of general insurers have very low efficiency scores. For example, the lowest 25 percent of general insurers have a pure technical efficiency index of 3.7 percent or lower, and a scale efficiency index of 7.3 percent or lower. The conclusion that there is a large number of general insurers with very low efficiency scores is further emphasised when the statistics on 'inefficient insurers' (ie. those with scores less than unity) are examined. In that case, the average pure technical efficiency is 39.1 percent, 53.8 percent for scale efficiency, 11.6 percent for allocative efficiency and only 10.0 percent for overall cost efficiency.

The results generally indicate that the larger portion of cost efficiency is the result of allocative, rather than technical (including scale), effects. In terms of international comparisons, Cummins and Weiss (1993) measured technical efficiencies of 90 percent in US property-liability insurers, Yeungert (1993) estimated technical inefficiencies from 35 to 50 percent in a sample of US life insurers, and Gardner \& Grace (1993) calculated average cost efficiencies of 42 percent in US life insurers. However, the results obtained from nonparameric techniques are highly sensitive to the actual sample along with the specification of inputs and outputs, and as indicators of relative efficiency should only be carefully compared to the results of other analyses.

TABLE 2.

Pure technical, scale, allocative and cost efficiency indices

\begin{tabular}{|c|c|c|c|c|c|c|c|c|c|c|c|c|}
\hline & \multicolumn{3}{|c|}{$\begin{array}{l}\text { Pure technical } \\
\text { efficiency }\end{array}$} & \multicolumn{3}{|c|}{ Scale efficiency } & \multicolumn{3}{|c|}{ Allocative efficiency } & \multicolumn{3}{|c|}{ Cost efficiency } \\
\hline & $\begin{array}{c}\text { All } \\
\text { insurers }\end{array}$ & $\begin{array}{l}\text { Inefficient } \\
\text { insurers }\end{array}$ & $\begin{array}{l}\text { Without } \\
\text { outliers }\end{array}$ & $\begin{array}{c}\text { All } \\
\text { insurers }\end{array}$ & $\begin{array}{l}\text { Inefficient } \\
\text { insurers }\end{array}$ & $\begin{array}{l}\text { Without } \\
\text { outliers }\end{array}$ & $\begin{array}{c}\text { All } \\
\text { insurers }\end{array}$ & $\begin{array}{c}\text { Inefficient } \\
\text { insurers }\end{array}$ & $\begin{array}{l}\text { Without } \\
\text { outliers }\end{array}$ & $\begin{array}{c}\text { All } \\
\text { insurers }\end{array}$ & $\begin{array}{c}\text { Inefficient } \\
\text { insurers }\end{array}$ & $\begin{array}{l}\text { Without } \\
\text { outliers }\end{array}$ \\
\hline Nur & 46 & 18 & 39 & 46 & 27 & 39 & 46 & 36 & 39 & 46 & 36 & 39 \\
\hline Mean & 0.762 & 0.391 & 0.764 & 0.729 & 0.538 & 0.769 & 0.309 & 0.116 & 0.311 & 0.296 & 0.100 & 0.291 \\
\hline Std. deviation & 0.331 & 0.227 & 0.318 & 0.310 & 0.275 & 0.293 & 0.403 & 0.185 & 0.400 & 0.410 & 0.188 & 0.410 \\
\hline First quartile & 0.037 & 0.037 & 0.037 & 0.073 & 0.073 & 0.073 & 0.008 & 0.008 & 0.014 & 0.001 & 0.001 & 0.002 \\
\hline Second quartile & 0.509 & 0.190 & 0.511 & 0.442 & 0.333 & 0.514 & 0.021 & 0.019 & 0.025 & 0.013 & 0.009 & 0.019 \\
\hline Third quartile & 1.000 & 0.399 & 1.000 & 0.916 & 0.482 & 0.944 & 0.047 & 0.033 & 0.054 & 0.030 & 0.020 & 0.042 \\
\hline Fourth quartile & 1.000 & 0.517 & 1.000 & 1.000 & 0.771 & 1.000 & 0.466 & 0.079 & 0.460 & 0.466 & 0.046 & 0.460 \\
\hline
\end{tabular}

Notes: Statistics relating to 'all insurers' includes entire sample, 'inefficient insurers' relates to those with an efficiency index $<1$, 'without outliers' are general insurers remaining after seven institutions with significantly higher cost-to-asset ratios were removed from the sample.

As a non-stochastic technique, one important consideration in DEA is the role of outliers in the sample. In order to address this concern, each insurer's ratio of total costs to total assets was examined; seven firms with exceptionally high ratios were removed from the sample, and the DEA calculations redone. The results of this sensitivity analysis indicate that the results are moderately robust with respect to the presence of outliers, with no dramatic changes in the average level of pure technical, scale, allocative and cost efficiency. Statistics relating to the sub-set of non-outlier insurers are also presented in Table 2.

The distribution of technical, allocative and cost efficiency across Australian general insurers is further investigated using a number of nonparametric techniques that are used to test for efficiency differences by asset size. It should be emphasised that the sample of 46 
insurers used in this analysis comprise the largest (by total assets) 43 percent of all Australian direct underwriters, and therefore excludes many smaller institutions. To construct these tests, the general insurers are divided into five equally sized groups on the basis of the book value of total assets. For example, the first group of insurers grouped on the basis of the book value of total assets consist of the largest twenty percent of insurance companies by asset size, the second group the next largest twenty percent, and so on.

The tests used are the Mann-Whitney and Kolmogorov-Smirnov tests. Test statistics and significance values are detailed in Table 3. The null hypothesis in the first instance is that the efficiency indices are equivalent in location across the selected groups, while in the second the null hypothesis is that the groups are equivalent in the shape and location of the efficiency distribution. To start with, the Mann-Whitney tests indicate that there are significant differences between the largest asset group and the next to largest group across all four measures of efficiency. However, none of the remaining tests of efficiency differences are significant across the groups and efficiency measures except for allocative and cost efficiency between the next to smallest twenty percent of insurers and the smallest twenty percent.

TABLE 3

\begin{tabular}{|c|c|c|c|c|c|}
\hline Test & Groups & $\begin{array}{c}\text { Pure } \\
\text { technical } \\
\text { efficiency }\end{array}$ & $\begin{array}{c}\text { Scale } \\
\text { efficiency }\end{array}$ & $\begin{array}{l}\text { Allocative } \\
\text { efficiency }\end{array}$ & $\begin{array}{c}\text { Cost } \\
\text { efficiency }\end{array}$ \\
\hline \multirow{8}{*}{ 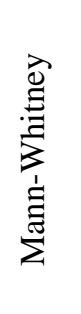 } & 1 and 2 & 61.000 & 59.000 & 49.500 & 49.500 \\
\hline & & $(0.017)$ & $(0.030)$ & $(0.001)$ & $(0.001)$ \\
\hline & 2 and 3 & 30.000 & 21.000 & 36.000 & 35.000 \\
\hline & & $(0.542)$ & (0.149) & $(1.000)$ & (0.923) \\
\hline & 3 and 4 & 29.000 & 34.000 & 32.500 & 32.500 \\
\hline & & $(0.477)$ & (0.888) & $(0.743)$ & $(0.736)$ \\
\hline & 4 and 5 & 49.000 & 38.500 & 5.000 & 22.000 \\
\hline & & (0.967) & $(0.372)$ & $(0.001)$ & $(0.037)$ \\
\hline \multirow{8}{*}{$\begin{array}{l}\partial \\
0 \\
. \\
0 \\
0 \\
0 \\
0 \\
0 \\
0 \\
0 \\
00 \\
0 \\
0 \\
1\end{array}$} & 1 and 2 & 1.143 & 1.543 & 1.829 & 1.829 \\
\hline & & $(0.146)$ & (0.017) & $(0.002)$ & $(0.002)$ \\
\hline & 2 and 3 & 0.772 & 1.058 & 0.572 & 0.772 \\
\hline & & $(0.591)$ & $(0.213)$ & $(0.899)$ & $(0.591)$ \\
\hline & 3 and 4 & 0.800 & 0.400 & 0.514 & 0.543 \\
\hline & & $(0.544)$ & (0.997) & $(0.954)$ & $(0.930)$ \\
\hline & 4 and 5 & 0.809 & 0.674 & 1.775 & 1.371 \\
\hline & & $(0.530)$ & $(0.754)$ & $(0.004)$ & $(0.047)$ \\
\hline
\end{tabular}

Notes: Values in brackets are $p$-values for tests of significance; equallysized groups are constructed on asset size (in millions of dollars) 1 $700+, 2-180$ to $699,3-55$ to $179,4-13$ to 54 , and $5-2$ to 12 .

The Kolmogorov-Smirnov test, provides broadly comparable statistically significant differences in the efficiency distributions. For instance, only the largest and smallest twenty percent of insurers have different distributions of allocative and cost efficiency, and only the largest twenty percent have a statistically different distribution of scale efficiency. Overall, these results would suggest that there are statistically significant differences in cost efficiency across Australian general insurers, and that largest twenty percent of insurers by asset size are considerably more cost efficient than the remainder.

The second stage of the analysis involves regressing the calculated efficiency indexes (pure technical, scale, allocative and cost) on a set of explanatory variables. Estimated coefficients, standard errors, $p$-values and marginal effects for the Tobit regressions are 
summarised in Table 4. The dependent variables for the four regressions in Table 4 are the DEA measures of pure technical, scale, allocative and cost efficiency. In brief, the explanatory variables are total assets $(A S T)$ and its square $\left(A S T^{2}\right)$, a Herfindahl index of product line concentration (HRF), and whether the insurer was listed (LST).

\section{TABLE 4}

Determinants of pure technical, scale allocative and cost efficiency

\begin{tabular}{|c|c|c|c|c|c|c|c|c|}
\hline & $\begin{array}{l}\text { Normalised } \\
\text { coefficient }\end{array}$ & $\begin{array}{l}\text { Standard } \\
\text { error }\end{array}$ & p-value & $\begin{array}{c}\text { Marginal } \\
\text { effect }\end{array}$ & $\begin{array}{l}\text { Normalised } \\
\text { coefficient }\end{array}$ & $\begin{array}{l}\text { Standard } \\
\text { error }\end{array}$ & p-value & $\begin{array}{l}\text { Marginal } \\
\text { effect }\end{array}$ \\
\hline & \multicolumn{4}{|c|}{ Pure technical efficiency } & \multicolumn{4}{|c|}{ Scale efficiency } \\
\hline CONS. & 8.1784 & 3.8009 & 0.0314 & & 3.9451 & 2.6096 & 0.1306 & \\
\hline AST & -1.4070 & 0.6783 & 0.0381 & -0.8864 & -0.5183 & 0.4577 & 0.2574 & -0.2426 \\
\hline $\mathrm{AST}^{2}$ & 0.0669 & 0.0303 & 0.0275 & 0.0421 & 0.0212 & 0.0202 & 0.2920 & 0.0099 \\
\hline LST & 5.1069 & 0.5358 & 0.0000 & 3.2173 & 0.1211 & 0.3047 & 0.6911 & 0.0566 \\
\hline HRF & 0.0323 & 0.4785 & 0.9461 & 0.0203 & -0.0448 & 0.3334 & 0.8931 & -0.0209 \\
\hline $\mathrm{R}^{2}$ & 0.1029 & & & & 0.0073 & & & \\
\hline \multirow[t]{2}{*}{ LR } & 10.7513 & & 0.0295 & & 2.4392 & & 0.6555 & \\
\hline & \multicolumn{4}{|c|}{ Allocative efficiency } & \multicolumn{4}{|c|}{ Cost efficiency } \\
\hline CONS. & 8.3600 & 1.6088 & 0.0000 & & 8.3816 & 1.6432 & 0.0000 & \\
\hline AST & -1.5524 & 0.2939 & 0.0000 & -0.4966 & -1.5625 & 0.2994 & 0.0000 & -0.5075 \\
\hline $\mathrm{AST}^{2}$ & 0.0734 & 0.0133 & 0.0000 & 0.0235 & 0.0740 & 0.0136 & 0.0000 & 0.0240 \\
\hline LST & 0.1501 & 0.1068 & 0.1598 & 0.0480 & 0.1628 & 0.1050 & 0.1209 & 0.0528 \\
\hline HRF & -0.1778 & 0.2105 & 0.3983 & -0.0569 & -0.1831 & 0.2138 & 0.3917 & -0.0594 \\
\hline $\mathrm{R}^{2}$ & 0.5270 & & & & 0.5255 & & & \\
\hline LR & 39.7590 & & 0.0000 & & 40.0480 & & 0.0000 & \\
\hline
\end{tabular}

Notes: AST and $\mathrm{AST}^{2}$ are the natural logarithm of total assets and its square; LST is a dummy variable indicating a listed company; HRF is a Herfindahl index of product line concentration. LR is the log-likelihood ratio test statistic that all slope coefficients are zero.

For the regressions where allocative efficiency and then cost efficiency are specified as the dependent variable, tests of the null hypothesises that all slope coefficients are zero are rejected at the 0.01 percent level using the log likelihood ratio procedure. The null hypothesis for the regression specifying pure technical efficiency as the dependent variable is rejected at the .05 level, while that for scale efficiency fails to be rejected. The hypotheses formulated above state that: (i) as assets increase, efficiency should increase, (ii) efficiency should increase as the firm's products becomes more diversified, and (iii) if the firm is publicly listed efficiency will be higher. The tobit regression using pure technical efficiency as the dependent variable yields results that indicate that total assets (AST) and totals assets squared $\left(A S T^{2}\right)$, are significant at the 0.05 level, and the dummy variable for stock listing is significant at the .01 level. The signs on the estimated coefficients for asset size, namely AST and $A S T^{2}$, are negative and positive respectively, indicating a non-linear relationship between firm size and efficiency. The marginal effect on pure technical efficiency for asset size and asset size squared is -0.8864 and 0.0421 respectively. The suggestion that medium-sized insurers are less efficient was also made by Meador et al. (2000). This also provides comparable evidence to the results obtained in the earlier nonparametric tests of efficiency differences in the current paper.

The regression results using scale efficiency as the dependent variable indicate that all of the estimated coefficients are insignificant. However, in the regressions where allocative efficiency and then cost efficiency are specified as the dependent variable, the estimated coefficients on the proxies for firm size (AST and $A S T^{2}$ ) are significant at the .01 level. This 
suggests that larger and smaller general insurers are associated with higher levels of pure technical, allocative and cost efficiency, while medium-sized insurers are generally less efficient. Once again, irrespective of the specification of the dependent variable, the measure of product line specialisation has no influence on the level of efficiency, refuting both the 'diversification and 'specialisation' hypothesises relating product focus to efficiency gains.

\section{CONCLUDING REMARKS}

A number of points emerge from the present study. The cost frontier measures indicate that in 1998 a typical Australian general insurer's costs were 53.4 percent above what could be considered necessary based on observable best practice. The main source of this cost inefficiency would appear to be allocative inefficiency, rather than technical inefficiency; that is, the inability of the firm to use inputs in optimal proportions, given the respective prices, rather than the inability of the firm to minimise inputs for a given level of output. Notwithstanding the low average level of efficiency across the industry, the study also indicates that the industry is divided between a smaller number of relatively efficient insurers, and a larger number of relatively inefficient insurers. This would suggest that the gap, in terms of both market share and efficiency, between the largest general insurance groups and the remaining firms that opened with a wave of mergers and joint ventures in the last two years of the twentieth century is likely to continue into the new millennium. Such pressures for consolidation are only likely to intensify with the further liberalisation of trade in insurance-related services negotiated by the WTO.

There are at least three ways in which this research may be extended. First, the approach used in this study could be expanded to include additional influences on general insurance provider efficiency. These may include variables related to regulatory and administrative frameworks, the degree of competition amongst insurers and other insurance-related services, and additional detail relating to the quantity and quality of services offered. Unfortunately, most of this information is not currently available and collection of such data would require ongoing cooperation between regulators, industry sources and researchers.

Second, in order to more fully examine the changing patterns of efficiency improvements, technological change and productivity gain since deregulation it may be useful to obtain estimators of general insurer efficiency using pooled time-series, cross-sectional data. This would not only provide consistent estimators of efficiency over time, but would also indicate improvements in efficiency due to deregulation and so on. One method could be the Malmquist index approach used by Cummins, Tennyson and Weiss (1999) to analyse productivity change in U.S life insurance companies and by Worthington $(1999,2000)$ to examine Australian deposit-taking institutions.

Finally, econometric techniques could be used to analyse Australian general insurance efficiency. In these approaches, the random error term is generally thought to encompass all events outside the control of the organisation, including both uncontrollable factors directly concerned with the 'actual' production function (such as differences in operating environments) and econometric errors (such as misspecification of the production function and measurement error) as against DEA which assumes that all deviations from the estimated frontier represent inefficiency. A number of previous studies have already used this approach to estimate the efficiency of insurance companies. These include Cummins \& Weiss (1993), Gardner \& Grace (1993), Rai (1996) and Berger et al. (1997).

\section{REFERENCES}


Australian Financial System Inquiry (1981). Australian Financial System: Final Report of the Committee of Inquiry into the Australian Financial System, Canberra, AGPS.

Banker, R.D., Charnes, A. \& Cooper, W.W. (1984). 'Some models for estimating technical and scale inefficiencies in data envelopment analysis’, Management Science, Vol. 30, pp. 1078-1092.

Berger, A.N., Cummins, J.D. \& Weiss, M.A. (1997). 'The coexistence of multiple distribution systems for financial services: The case of property-liability insurance', Journal of Business, Vol. 70, pp. 515-546.

Berger, A.N. \& Humphrey, D.B. (1993). 'Measurement and efficiency issues in commercial banking' In: Z. Griliches (ed) Output Measurement in the Service Sector, pp. 245-279, Chicago, University of Chicago Press.

Berger, A,N. \& Humphrey, D.B. (1997). 'Efficiency of financial institutions: International survey and directions for future research’, European Journal of Operational Research, Vol. 98, pp. 175-212.

Bernstein, J. (1992). 'Information spillovers, margins, scale and scope: With an application to Canadian life insurance’, Scandinavian Journal of Economics, Vol. 94, pp. 95-105.

Charnes, A., Cooper W.W. \& Rhodes, E. (1978). 'Measuring the efficiency of decision making units', European Journal of Operational Research, Vol. 2, pp. 429-444.

Coelli, T., Rao, D.S.P. \& Battese, G.E. (1997). An Introduction to Efficiency and Productivity Analysis, Kluwer, Boston.

Cooper, W.W., Seiford, L.M. \& Tone, K. (2000). Data Envelopment Analysis: A Comprehensive Text with Models, Applications, References and DEA-Solver Software, Kluwer, Boston.

Cummins, J., Tennyson, S. \& Weiss, M. (1999). 'Consolidation and efficiency in the US life insurance industry’, Journal of Banking and Finance, Vol. 23, pp. 325-357.

Cummins, J. \& Van Derhei, J. (1979). 'A note on the relative efficiency of property-liability insurance distribution systems', Bell Journal of Economics, Vol. 10, pp. 709-719.

Cummins, J. \& Weiss, M. (1993). 'Measuring cost efficiency in the property-liability insurance industry', Journal of Banking and Finance, Vol. 17, pp. 463-481.

Cummins, J. \& Zi, H. (1998). 'Comparisons of frontier efficiency methods: An application to the US life insurance industry’, Journal of Productivity Analysis, Vol. 10, pp. 131-152.

Cummins, J.D. \& Santomero, A.M. (1999). Changes in the Life Insurance Industry: Efficiency, Technology and Risk Management, Boston, Kluwer.

Cummins, J.D., Weiss, M.A. \& Zi, H. (1999). 'Organisational form and efficiency: The coexistence of stock and mutual property-liability insurers’, Management Science, Vol. 45, pp. 1254-1269.

Doherty, N. (1981). 'The measurement of output and economies of scale in property-liability insurance', Journal of Risk and Insurance, Vol. 48, pp. 391-404.

Fields, J. (1988). 'Expense preference behaviour in mutual life insurers', Journal of Financial Services Research, Vol. 1, pp. 113-129.

Fields, J. \& Murphy, N. (1989). 'An analysis of efficiency in the delivery of financial services: The case of life insurance agencies’, Journal of Financial Services Research, Vol. 2, pp. 323-356.

Financial System Inquiry (1997). Financial System Inquiry: Final Report, Canberra, AGPS.

Fukuyama, H. (1997). 'Investigating productive efficiency and productivity changes of Japanese life insurance companies’, Pacific-Basin Finance Journal, Vol. 5, pp. 481-509.

Gardner, L. \& Grace, M. (1993). 'X-efficiency in the US life insurance industry', Journal of Banking and Finance, Vol. 17, pp. 497-510.

Grace, M. \& Timme, S. (1992). 'An examination of economies of scale and scope in the US life insurance industry’, Journal of Risk and Insurance, Vol. 24, pp. 72-103.

Hardwick, P. (1997). 'Measuring cost inefficiency in the UK life insurance industry', Applied Financial Economics, Vol. 7, pp. 37-44.

Houston, D. \& Simon, R. (1970). 'Economies of scale in financial institutions: A study of life assurance', Econometrica, Vol. 38, pp. 856-864.

KPMG (1999). The 1999 Insurance Industry Survey, Sydney, KPMG.

McIntosh, J. (1998). 'Scale efficiency in a dynamic model of Canadian insurance companies', Journal of Risk and Insurance, Vol. 65, pp. 303-317.

Meador, J.W., Ryan, H.E. \& Schellhorn, C.D. (2000). 'Product focus versus diversification: Estimates of Xefficiency for the U.S. life insurance industry’ In: P.T. Harker \& S. Zenios (eds) Performance of Financial Institutions, pp. 175-199, Cambridge, Cambridge University Press.

Praetz, P. (1980). 'Returns to scale in the life insurance industry', Journal of Risk and Insurance, Vol. 47, pp. 525-532.

Prosperetti, L. (1991). 'Economies of scale in Italian non-life insurance', The Geneva Papers on Risk and Insurance, Vol. 16, pp. 282-292. 
Rai, A. (1996). 'Cost efficiency of international insurance firms', Journal of Financial Services Research, Vol. 10, pp. 213-233.

Weiss, M. (1981). 'Analysis of productivity at the firm level', Journal of Risk and Insurance, Vol. 53, pp. 5084.

World Trade Organisation (2000). 'The Results of the Financial Services Negotiations under the General Agreement on Trade in Services', http://www.wto.org/.

Worthington, A.C. (1999). 'Malmquist indices of productivity change in Australian financial services', Journal of International Financial Markets, Institutions and Money, Vol. 9, pp. 303-320.

Worthington, A.C. (2000). 'Technical efficiency and technological change in Australian building societies', Abacus, Vol. 36, pp. 180-197.

Yuengert, A. (1993). 'The measurement of efficiency in life insurance: Estimates of a mixed normal-gamma error model', Journal of Banking and Finance, Vol. 17, pp. 483-496. 